\title{
GMR
}

\section{Geometry applied to breeding common beans (Phaseolus vulgaris)}

\author{
J.G. Lima and M.A.P. Ramalho \\ Departamento de Biologia, Universidade Federal de Lavras, Lavras, MG, Brasil \\ Corresponding author: J.G. Lima \\ E-mail: gentiljessica@yahoo.com.br \\ Genet. Mol. Res. 15 (2): gmr.15027873 \\ Received October 21, 2015 \\ Accepted December 7, 2015 \\ Published April 25, 2016 \\ DOI http://dx.doi.org/10.4238/gmr.15027873
}

\begin{abstract}
The primary components of common bean (Phaseolus vulgaris) grain yield (W) are the number of pods $(\mathrm{X})$, the number of grains per pod (Y), and the weight of the grains (Z). In 1964, Grafius suggested using geometry in plant breeding; W corresponds to the volume of a parallelepiped with three axes, X, Y, and Z. Because the cube is the largest parallelepiped by volume, maximum yield is obtained when the relative contributions of $\mathrm{X}, \mathrm{Y}$, and $\mathrm{Z}$ are the same. We evaluated individual plants of a 'Talismã' $x$ 'L.59583' cross in two sowing periods. The sum of squares of deviations from the ideal plant (GI), i.e., the plant in which the $\mathrm{X}, \mathrm{Y}$, and $\mathrm{Z}$ contributions were the same, was estimated. Mean and variance genetic components, and genetic and phenotypic correlations between the characteristics were also estimated. Good concordance was observed in the magnitude and direction of the genetic and phenotypic correlation estimates of the paired characteristics. However, a low GI heritability $\left(h^{2}{ }_{r}=6.7 \%\right)$ indicated that success due to selection should be small. Ninety-four progenies of 'Pérola' $x$ 'ESAL 686' crosses were also evaluated, where $\mathrm{X}, \mathrm{Y}, \mathrm{Z}$, and W were obtained and GI was estimated. The $h^{2}$ estimate was higher, but still low $\left(h^{2}=39.0 \%\right)$. Therefore, the selection of individuals to obtain plants in which the $\mathrm{X}, \mathrm{Y}$, and $\mathrm{Z}$ products tend to
\end{abstract}


the cube is unfeasible, because the sums of $\mathrm{X}, \mathrm{Y}$, and $\mathrm{Z}$ vary between individuals. In addition, the GI $h^{2}$ value was low.

Key words: Plant breeding; Phaseolus vulgaris; Primary component; Genetic component; Heritability

\section{INTRODUCTION}

Almost all plant genes are involved in grain yield. However, these genes act indirectly, i.e., there are no specific yield genes. Therefore, it is possible to identify a hierarchical structure of roles among different organs and tissues that will ultimately influence grain yield. Primary yield components are characteristics that directly influence the final characteristic. In the case of common bean (Phaseolus vulgaris) plants, these characteristics are the number of pods per plant $(X)$, the number of grains per pod $(Y)$, and the weight of each grain $(Z)$. The product of $\mathrm{X}, \mathrm{Y}$, and $\mathrm{Z}$ is grain yield (W).

Several studies have reported positive correlations between the X, Y, and Z components and yield (Ramalho et al., 1979; Santos et al., 1985; Coelho et al., 2002; Lana et al., 2003), and that correlations between $\mathrm{X}$ and $\mathrm{Y}, \mathrm{X}$ and $\mathrm{Z}$, and $\mathrm{Y}$ and $\mathrm{Z}$ are usually negative.

$\mathrm{W}$ is the product of $\mathrm{X}, \mathrm{Y}$, and $\mathrm{Z}$; therefore, three axes describe yield as the volume of a parallelepiped. The cube is the largest parallelepiped by volume, i.e., the three axes contribute equally to the volume (Grafius, 1964). Despite the fact that Grafius's ideas are well-founded and were suggested over 50 years ago, to our knowledge, no studies have attempted to identify lines and/or plants in which the relative contributions of these components are as similar as possible in order to increase yield. Therefore, it is important to investigate whether it is possible to identify individuals with similar $\mathrm{X}, \mathrm{Y}$, and $\mathrm{Z}$ contributions based on a segregating population for the three characteristics. We estimated the genetic and phenotypic parameters of these relative contributions in order to ascertain whether selection aimed at obtaining more productive bean cultivars would be successful.

\section{MATERIAL AND METHODS}

The experiments were conducted in a greenhouse and in the field at the Biology Department Experimental Area, Federal University of Lavras (UFLA), Brazil. Lavras County is in southern Minas Gerais State, Brazil, at $918 \mathrm{~m}$ above mean sea level, and latitude $21^{\circ} 58^{\prime} \mathrm{S}$ and longitude $42^{\circ} 22^{\prime} \mathrm{W}$.

Two types of experiments were conducted. The first experiment was based on information about individual plants from a cross of the BRSMG 'Talismã' $\left(\mathrm{P}_{1}\right)$ cultivar, which was used as the female parent, and the ' 59583 ' $\left(\mathrm{P}_{2}\right)$ line, which was used as the male parent. The $F_{1}$ seeds were obtained in a greenhouse at the UFLA Biology Department, and the $F_{2}$ and $\mathrm{F}_{3}$ generations were obtained in the field.

The experiment was conducted with a randomized block design with two replications, and five treatments were included: both parents and the $\mathrm{F}_{1}, \mathrm{~F}_{2}$, and $\mathrm{F}_{3}$ generations. The parent and $\mathrm{F}_{1}$ plots consisted of one 1-m row. The $\mathrm{F}_{2}$ and $\mathrm{F}_{3}$ plots contained 101 -m rows. The rows were $60 \mathrm{~cm}$ apart, with 10 seeds per linear meter. The seeds were sown in February 2013.

All of the data were collected from individual plants at harvest. The following characteristics were recorded: the number of pods per plant $(\mathrm{X})$, obtained by counting all of 
the pods on each plant; the number of grains per pod (Y), obtained by dividing the number of grains produced by the plant by the number of pods; and yield per plant (g), obtained by weighing the grains from each plant. The 100-grain weight was estimated using these data, and the weight of one grain $(\mathrm{Z})$ was used for data analysis. The $\mathrm{X}, \mathrm{Y}$, and $\mathrm{Z}$ data were used to estimate the relative contributions of each characteristic to the grain yield per plant. $\mathrm{Y}_{R i}$ and $\mathrm{Z}_{R i}$ were similarly obtained. By taking into consideration that the cube is the largest parallelepiped by volume, and that its axes contribute equally, the sum of squares of deviations from the geometrically ideal model of the plant $i\left(G I_{i}\right)$ was estimated as:

$$
G I_{i}=\left(\mathrm{X}_{R i}-0.3333\right)^{2}+\left(\mathrm{Y}_{R i}-0.3333\right)^{2}+\left(\mathrm{Z}_{R i}-0.3333\right)^{2} \quad \text { (Equation 1) }
$$

The mean and variance genetic components were obtained from the estimates of means and variances of the parents and segregating populations. An additive-dominant model without epistasis was used. The weighted least squares method was employed, as described by Ramalho et al. (2012). Heterosis $(h)$ and narrow-sense heritability $\left(h^{2}\right)$ were estimated at the individual level (Bernardo, 2010). Phenotypic and genetic correlations between all combinations of the pairs of characteristics were obtained using the procedure suggested by Falconer and Mackay (1996).

The expected gain with selection (SG) was estimated for the X, Y, Z, W, and GI characteristics by considering the top 10 individuals, as well as the $C R_{j(G I)}$ (correlated response) in characteristic $j(\mathrm{X}, \mathrm{Y}, \mathrm{Z}$, or $\mathrm{W})$ by the selection of $\mathrm{GI}$.

The second experiment evaluated $94 \mathrm{~F}_{3: 5}$ progenies from a 'Pérola' $\mathrm{x}$ 'ESAL 686' cross. These progenies, as well as the two parents and four controls, were evaluated using a 10 x 10-triple-lattice design. Seeds were sown in rows spaced $60 \mathrm{~cm}$ apart, and data were collected from three randomly selected plants in the plot. The same characteristics that were measured in the experiments with individual plants were recorded in this experiment, and GI was estimated in a manner similar to that described for the first experiment. All of the data were subjected to variance analysis. Narrow-sense heritability $\left(h^{2}\right)$ was estimated based on the expected mean squares, by considering all of the random effects except the mean. The SG was also estimated by considering the top 10 progenies and the $\mathrm{CR}$, in a manner similar to that described for individual plants.

\section{RESULTS}

The means for X (number of pods), Y (number of grains per pod), and W (yield per plant) suggested that there was great divergence between the parents. Regarding $\mathrm{X}$ and $\mathrm{W}$, the $\mathrm{F}_{1}$ mean was far higher than the other means, showing dominance in the characteristic's expression, which was confirmed by the heterosis estimates. It was also observed that the GI mean estimate, namely the sum of squares of deviations from the geometrically ideal plant, exhibited variation between the parents and between the segregating generations. Dominance was also prevalent; however, the heterosis estimate was lower than that for X and W (Table 1).

The additive-dominant model without epistasis explained most of the variation when the mean components were estimated for all of the characteristics evaluated (X, Y, Z, W, and GI). In all cases, the $R^{2}$ in the model was higher than $95 \%$. The component that estimated the homozygote deviation from the mean $(a)$ and the heterozygous contribution $(d)$ was different from zero in most cases. 
Table 1. Estimates of means $(m)$, phenotypic variance $(v)$, and heterosis $(h)$ for the number of pods $(X)$, number of grains per pod (Y), weight of grains $(\mathrm{Z})$, yield per plant $(\mathrm{W})$, and the sum of squares of deviations from the geometrically ideal plant (GI).

\begin{tabular}{l|c|c|c|c|c|c|c|c|c|c}
\hline & & $\mathrm{X}$ & & $\mathrm{Y}$ & & $\mathrm{Z}$ & $\mathrm{W}$ & & \multicolumn{2}{c}{ GI } \\
\hline & $m$ & $v$ & $m$ & $v$ & $m$ & $v(\mathrm{x} 100)$ & $m$ & $v$ & $m$ & $v(\mathrm{x} 100)$ \\
\hline $\mathrm{P}_{1}$ & 21.54 & 9.93 & 4.76 & 0.29 & 0.21 & 0.07 & 21.82 & 3.33 & 0.36 & 0.20 \\
\hline $\mathrm{P}_{2}$ & 13.71 & 9.90 & 1.78 & 0.11 & 0.22 & 0.09 & 5.96 & 4.49 & 0.44 & 0.16 \\
\hline $\mathrm{F}_{1}$ & 48.90 & 5.88 & 3.74 & 0.02 & 0.28 & 0.02 & 50.39 & 8.11 & 0.52 & 0.006 \\
\hline $\mathrm{F}_{2}$ & 27.25 & 76.59 & 3.45 & 1.14 & 0.23 & 0.15 & 22.33 & 6.97 & 0.45 & 0.62 \\
\hline $\mathrm{F}_{3}$ & 25.31 & 73.30 & 3.65 & 0.82 & 0.21 & 0.13 & 19.01 & 9.51 & 0.42 & 0.53 \\
\hline $\mathrm{h}(\%)$ & \multicolumn{3}{|c|}{63.95} & \multicolumn{3}{|c|}{12.57} & \multicolumn{3}{|c|}{72.44} & \multicolumn{2}{c}{24.48} \\
\hline
\end{tabular}

Data were obtained from a 'Talismã' $\left(\mathrm{P}_{1}\right) \mathrm{x}$ 'L.59583' $\left(\mathrm{P}_{2}\right)$ cross.

Dominance was evidenced by the magnitude of the $d$ estimates; all of them were different from zero (Table 2). The estimates of phenotypic and genetic variance components also varied between the X, Y, Z, W, and GI characteristics (Table 2). The model without epistasis explained most of the variation $\left(R^{2}\right.$ greater than $\left.90 \%\right)$. The additive variance $\left(V_{A}\right)$ and dominance variance $\left(V_{D}\right)$ components were different from zero, except for $Y$, and were similar to those found in previous studies. Heritability $\left(h^{2}\right)$ differed between the characteristics; it was high for $\mathrm{W}$ and almost zero for $\mathrm{Y}$ and $\mathrm{Z}$. The GI estimate was also low (Table 2).

Table 2. Estimates of mean components ( $\hat{m}, \hat{a}$, and $\hat{d}$ ), environmental variance components $\left(\hat{V}_{e}\right)$, additive genetic variance $\left(\hat{V}_{A}\right)$, dominance variance $\left(\hat{V}_{D}\right)$, and narrow-sense heritability $h_{r}^{2}$ of the number of pods $(\mathrm{X})$, number of grains per pod $(\mathrm{Y})$, weight of grains $(\mathrm{Z})$, yield per plant $(\mathrm{W})$, and the sum of squares of deviations from the geometrically ideal plant (GI).

\begin{tabular}{l|c|c|c|c|c}
\hline Parameter & $\mathrm{X}$ & $\mathrm{Y}$ & $\mathrm{Z}$ & $\mathrm{W}$ & $\mathrm{GI}$ \\
\hline$\hat{m}$ & 16.56 & 3.39 & 0.195 & 11.8 & 0.39 \\
\hline & $\left(0.60^{* *}\right)$ & $\left(0.07^{* *}\right)$ & $\left(0.4^{* *}\right)^{1}$ & $\left(0.34^{* *}\right)$ & $\left(0.62^{* *}\right)^{1}$ \\
\hline$\hat{a}$ & 4.42 & 1.49 & 0.003 & 8.93 & ${ }^{1}$ \\
\hline & $\left(0.71^{* *}\right)$ & $\left(0.09^{* *}\right)$ & $\left(0.6^{\mathrm{NS}}\right)$ & $\left(0.45^{* *}\right)$ & $\left(0.97^{* *}\right)$ \\
\hline$\hat{d}$ & 30.72 & 0.35 & 0.079 & 26.40 & 0.13 \\
\hline $\mathrm{R}^{2}$ & $\left(1.03^{* *}\right)$ & $\left(0.08^{* *}\right)$ & $\left(0.7^{* *}\right)$ & $\left(0.81^{* *}\right)$ & $\left(0.69^{* *}\right)$ \\
\hline$\hat{V}_{e}$ & 99.45 & 99.93 & 99.88 & 99.99 & 97.66 \\
\hline & 8.57 & 0.155 & $0.58^{3}$ & 5.21 & 0.0012 \\
\hline$\hat{V}_{A}$ & $(0.05)^{2}$ & $(0.05)$ & $(0.05)$ & $(0.05)$ & $(0.05)$ \\
\hline$\hat{V}_{D}$ & 18.28 & -0.09 & 0.038 & 3.97 & 0.0004 \\
\hline & $(0.32)$ & $(0.65)$ & $(0.89)$ & $(0.13)$ & $(0.72)$ \\
\hline $\mathrm{R}^{2}$ & 49.73 & 1.08 & 0.87 & -2.21 & 0.0044 \\
\hline $\mathrm{h}_{\mathrm{r}}^{2}(\%)$ & $(0.16)$ & $(0.08)$ & $(0.19)$ & $(0.44)$ & $(0.13)$ \\
\hline $\mathrm{A}$ & 99.41 & 99.93 & 96.87 & 97.53 & 92.13 \\
\hline
\end{tabular}

${ }^{1}$ Associated standard errors (x 100). ${ }^{2}$ Probability according to the Student $t$-test. ${ }^{3}$ Estimate (x 1000). ${ }^{* *}$ Component significantly different from zero at the $1 \%$ probability level according to the Student $t$-test; NS = not significant; $\mathrm{R}^{2}$ $=$ model determination coefficient. Data were obtained from a 'Talismã' x 'L.59583' cross.

Overall, there was good concordance between the magnitude and direction of the genetic and phenotypic correlation estimates of the paired characteristics. The $\mathrm{X}$ and $\mathrm{W}$ correlation estimate exhibited the greatest magnitude, i.e., the number of pods was the primary 
component that best explained the grain yield variation per plant. The correlation between GI and $\mathrm{W}$ was of most interest to the current study; the phenotypic correlation was positive, against all expectations. However, although significant, the magnitude was not expressive (Table 3).

Table 3. Estimates of phenotypic (below the diagonal) and genetic (above the diagonal) correlations between the number of pods $(\mathrm{X})$, number of grains per pod $(\mathrm{Y})$, weight of grains $(\mathrm{Z})$, yield per plant $(\mathrm{W})$, and the sum of squares of deviations from the geometrically ideal plant (GI).

\begin{tabular}{l|c|c|c|c|c}
\hline & $\mathrm{X}$ & $\mathrm{Y}$ & $\mathrm{Z}$ & $\mathrm{W}$ & $\mathrm{GI}$ \\
\hline $\mathrm{X}$ & 1 & -0.30 & 0.30 & 0.80 & 0.99 \\
\hline $\mathrm{Y}$ & $-0.25^{* *}$ & 1 & -0.73 & 0.47 & -0.98 \\
\hline $\mathrm{Z}$ & $0.20^{* *}$ & $-0.46^{* *}$ & 1 & 0.21 & 0.57 \\
\hline $\mathrm{W}$ & $0.70^{* *}$ & $0.40^{* *}$ & $0.14^{\mathrm{NS}}$ & 1 & 0.27 \\
\hline $\mathrm{GI}$ & $0.80^{* *}$ & $-0.75^{* *}$ & $0.37^{* *}$ & $0.21^{* *}$ & 1 \\
\hline
\end{tabular}

**Significant at the $1 \%$ probability level according to the Student $t$-test. NS $=$ not significant.

The expected gain caused by the selection of the top 10 individuals in the $\mathrm{F}_{2}$ generation was also estimated. It should be emphasized that individuals that exhibited the highest phenotypic value were the best for the $\mathrm{X}, \mathrm{Y}, \mathrm{Z}$, and $\mathrm{W}$ characteristics, and those exhibiting the lowest value were the best for GI. Therefore, the SG estimate for GI was negative (Table 4).

Table 4. Estimates of the selection-based expected gain $(S G \%)$ for the number of pods (X), number of grains per pod $(\mathrm{Y})$, weight of grains $(\mathrm{Z})$, yield per plant $(\mathrm{W})$, and the sum of squares of deviations from the ideal plant (GI), and correlated response to selection for $\mathrm{GI}\left(C R_{j(G I)} \%\right)$ and gain in the $\mathrm{X}, \mathrm{Y}, \mathrm{Z}$, and $\mathrm{W}$ characteristics.

\begin{tabular}{l|c|c|c|c|c}
\hline \multirow{2}{*}{ Estimate } & \multicolumn{4}{|c}{ Characteristics } \\
\cline { 2 - 5 } & GI & X & Y & $\mathrm{Z}$ & $\mathrm{W}$ \\
\hline$h^{2}$ & 6.66 & 23.07 & 0.00 & 2.55 & 56.96 \\
\hline$S G_{j} \%$ & -11.5 & 21.68 & 0.00 & 0.71 & 46.62 \\
\hline$C R_{j(G I)} \%$ & - & -9.24 & 0.00 & -0.23 & -10.31 \\
\hline
\end{tabular}

The selection-based expected gain in mean percentage was only zero for the $\mathrm{Y}$ characteristic, and its highest value was for the $\mathrm{W}$ characteristic. The GI estimate was negative, and was of intermediate magnitude for the other characteristics. The response that was correlated with the selection, conducted in the 10 individuals, with the lowest GI values was negative in all cases, where $h^{2}$ was different from zero. Once selection had been performed in individuals with low GI values, there may have been reduced phenotypic expression in $\mathrm{X}, \mathrm{Z}$, and $\mathrm{W}$.

Regarding the experiment with progenies, estimates for the $\mathrm{X}, \mathrm{Y}, \mathrm{Z}$, and $\mathrm{W}$ characteristics were fairly accurate (Table 5). Heritability estimates for mean selection revealed that the weight of the grains $(\mathrm{Z})$ had the highest mean (Table 6). The other values were lower than $50 \%$, which indicates that they were all strongly influenced by the environment.

The $h_{r}^{2}$ estimate for GI in the progenies was much higher than that obtained using individual plant data (Tables 2 and 6). The lowest estimate of the SG was found in relation to GI. However, the correlated response to selection performed on GI was negative for the $\mathrm{X}$ characteristic. It was low for the $\mathrm{Z}$ and $\mathrm{W}$ characteristics, although these estimates were positive (Table 6). 
Table 5. Summary of a variance analysis on the number of pods $(X)$, number of grains per pod $(Y)$, weight of grains (Z), yield per plant (W), and the sum of squares of deviations from the ideal plant (GI).

\begin{tabular}{l|c|c|c|c|c}
\hline \multirow{2}{*}{ Characteristic } & \multicolumn{2}{|c|}{ Progeny } & \multicolumn{2}{c|}{ Error } & \multirow{2}{*}{ Accuracy } \\
\cline { 2 - 5 } & d.f. & MS & d.f. & MS & \\
\hline $\mathrm{X}$ & 99 & $110.9451^{* *}$ & 163 & 57.3993 & 63 \\
\hline $\mathrm{Y}$ & 99 & $2.4294^{* *}$ & 163 & 1.2852 & 68 \\
\hline $\mathrm{Z}$ & 99 & $0.0082^{* *}$ & 163 & 0.0032 & 78 \\
\hline $\mathrm{W}$ & 99 & $152.05^{* *}$ & 163 & 0.0032 & 62 \\
\hline GI & 99 & $0.0065^{* *}$ & 163 & 0.0042 & 55 \\
\hline
\end{tabular}

d.f. $=$ degrees of freedom; MS $=$ mean of squares. ${ }^{* *}$ Component significantly different from zero at the $1 \%$ probability level according to the Student $t$-test.

Table 6. Heritability $\left(h^{2}\right)$ and selection-based expected gain estimates $(S G \%)$ for the number of pods $(\mathrm{X})$, number of grains per pod (Y), weight of grains $(\mathrm{Z})$, yield per plant $(\mathrm{W})$, and the sum of squares of deviations from the ideal plant $(\mathrm{GI})$, and correlated response to selection for $\mathrm{GI}\left(C R_{j(G)} \%\right)$ and gain in the $\mathrm{X}, \mathrm{Y}, \mathrm{Z}$, and W characteristics.

\begin{tabular}{l|c|c|c|c|c}
\hline \multirow{2}{*}{ Estimate } & \multicolumn{3}{|c}{ Characteristics } & Z & W \\
\cline { 2 - 7 } & GI & X & Y & 62.00 & 39.00 \\
\hline$h^{2}$ & 31.00 & 41.00 & 46.00 & 13.92 & 13.40 \\
\hline$S G_{j} \%$ & -3.96 & 11.06 & 7.67 & 1.04 & 2.48 \\
\hline$C R_{j(G I)} \%$ & - & -9.45 & 7.23 & \\
\hline
\end{tabular}

\section{DISCUSSION}

There was great variation in all of the characteristics when individual plants were evaluated (Table 1), because both parents were quite divergent. The 'Talismã' cultivar is adapted to the region, and 'L.59583' is a wild bean, which was used because it produces a large number of flowers in a few inflorescence. The progenies also exhibited great variation, again because of genetic divergence between the parents. The 'Pérola' cultivar belongs to the Mesoamerican-type cultivar group, whereas the 'ESAL 686' line is typically Andean. They markedly differ from each other in grain size, with reflex in the other characteristics. Variation in $\mathrm{X}, \mathrm{Y}$, and $\mathrm{Z}$ is essential when applying the geometric concept in plant breeding.

Genetic control of the X, Y,Z, and W characteristics in the 'Talismã' $X$ 'L.59583' cross showed that the model without epistasis explained most of the variation. The $d$ component, which measured the heterozygote deviation from the mean, was higher than $a$ for X, Z, and W. This indicates dominance, which was confirmed by the heterosis estimates. The dominance variance was also significant when the variance components were evaluated in the same cross, except for $\mathrm{W}$, which was zero (Table 2).

There is controversy in the literature concerning the presence of dominance in the expression of the $\mathrm{X}, \mathrm{Y}, \mathrm{Z}$, and $\mathrm{W}$ characteristics. The findings of the current study corroborate those of Santos et al. (1985), i.e., the occurrence of dominance. Some studies have reported that additive effects are more important (Sarafi, 1978; Souza and Ramalho, 1995). One possible explanation for the occurrence of significant dominance effects is the fact that 'L.59583' is not adapted and is quite divergent from 'Talismã'. Dominance is expected to be more prevalent under these conditions. In addition, the plants were sown with large spaces between them that reduced competition, which increased dominance.

As already mentioned, higher $h^{2}$ estimates were obtained when the progenies were evaluated (Table 6). This was expected, because the mean phenotypic variance, which 
dominates $h^{2}$ expression, was obtained from the mean square of the progeny variation source divided by the number of replications. This was also found in an $h^{2}$ survey conducted by Ramalho et al. (2012), who reported estimates using plants and progenies.

The most relevant genetic control information in the current study was GI, i.e., the sum of squares of deviations from the geometrically ideal plant. Regarding the use of means and variances, the result was very similar to that observed in the other characteristics, as expected, i.e., the $d$ estimate was higher than that of $a$. These results indicate dominance in the characteristic's expression, as it also occurred in the other characteristics. However, the $h^{2}$ estimates, both in the progenies and particularly in the individual plants, were lower than that for grain yield. This result shows that selection success in GI will be lower than that in W.

The $\mathrm{X}, \mathrm{Y}$, and Z primary components have positive and strong genetic and phenotypic correlations with grain yield (Cabral et al., 2011; Zilio et al., 2011; Ribeiro et al., 2014), an observation that was supported by the results of the current study (Table 3). However, the correlations were negative or weak between $\mathrm{X}$ and $\mathrm{Y}, \mathrm{X}$ and $\mathrm{Z}$, and $\mathrm{Y}$ and $\mathrm{Z}$.

The correlation estimates involving GI, particularly yield, were the most important data in the current study. Both the genetic and the phenotypic correlation estimates were low, indicating that GI was not strongly associated with $\mathrm{W}$ and was not negative, as it was expected to be. As already mentioned, the reason for this may be the fact that the GI estimate per se does not take under consideration the sum of $\mathrm{X}+\mathrm{Y}+\mathrm{Z}$, which reduces the possibility of selecting a low GI estimate in order to increase yield.

The current study aimed to investigate the relative contributions of $\mathrm{X}, \mathrm{Y}$, and $\mathrm{Z}$ to yield per plant (W). According to Grafius (1964), geometry may help with this. W is the product of the axes X, Y, and Z; therefore, $\mathrm{W}$ can be represented by the volume of a parallelepiped. The cube is the largest parallelepiped by volume, i.e., the volume is large when the relative contributions of the axes are similar. However, a parallelepiped may have different axis dimensions, and $\mathrm{X}$, $\mathrm{Y}$, and $\mathrm{Z}$ may differ between plants. The only alternative is to find situations in which the sums of $\mathrm{X}, \mathrm{Y}$, and $\mathrm{Z}$ are similar and their relative contributions vary. For example, two $\mathrm{F}_{2}$ 'Talismã' x 'L.59583' plants had similar X, Y, and Z sums but different GI values (Figure 1). For the plant with a low GI value, the parallelepiped volume was large and the geometric figure tended towards the cube (see Grafius, 1964).

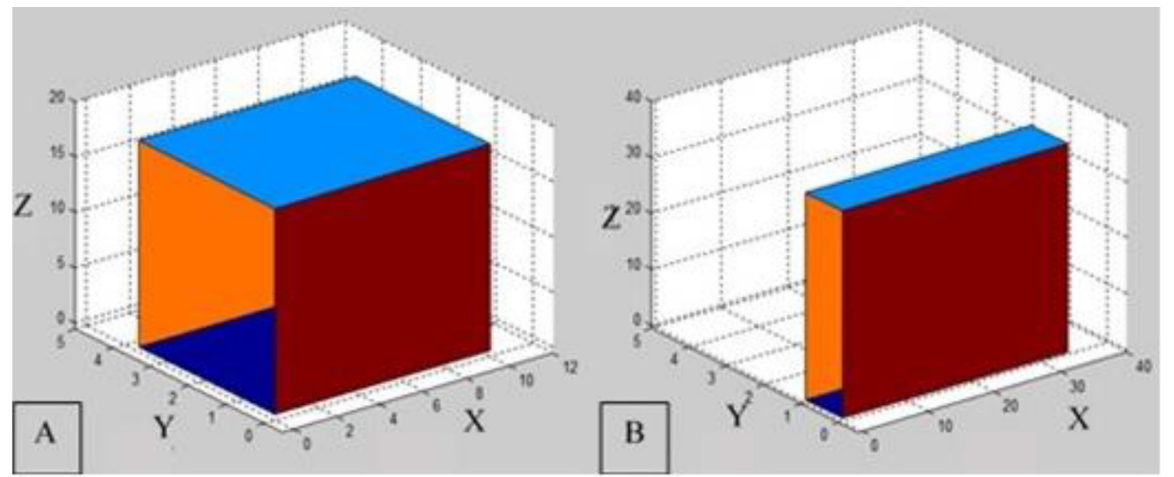

Figure 1. Volume of the parallelepiped, representing yield per bean plant according to its primary components: number of pods (X), number of grains per pod (Y), and weight of grains x $100(\mathrm{Z})$. A. Plant with a low sum of squares of deviations from the geometrically ideal plant (GI); B. plant with a higher GI value. Data were obtained from the $\mathrm{F}_{2}$ generation of a 'Talismã' $\mathrm{x}$ 'L.59583' cross, and two plants with similar X+Y $+\mathrm{Z}$ sums were used. 
An index involving the GI value and the $\mathrm{X}+\mathrm{Y}+\mathrm{Z}$ sum $\left(\sum \mathrm{GI}\right)$ could be used to solve this problem. Because the lowest GI value is the most relevant, this should be multiplied by -1 in order to obtain the index. Therefore, the $\Sigma$ GI value should be low when the relative contributions of $\mathrm{X}, \mathrm{Y}$, and $\mathrm{Z}$ deviate from the ideal. The correlation between $\Sigma \mathrm{GI}$ and $\mathrm{W}$ was strong and positive $\left(r_{F}=0.77\right.$ in individual plants and $r_{F}=0.73$ in progenies). Although Grafius's (1964) idea is mathematically correct, its use is inappropriate when improving selection efficiency for grain yield. GI has a low heritability, and there will be few situations in which the $\mathrm{X}, \mathrm{Y}$, and $\mathrm{Z}$ sums are similar among all plants and/or progenies. In addition, evaluating yield is less laborious than evaluating yield's primary components, and grain weight is a characteristic of commercial interest and cannot deviate from the standard.

\section{CONCLUSIONS}

The use of geometry in plant breeding is inappropriate, because comparisons between individuals and/or progenies are only feasible if they have similar $\mathrm{X}+\mathrm{Y}+\mathrm{Z}$ sums, which rarely occurs. Furthermore, heritability of the GI characteristic, which measures the deviation of the sum of squares of the $\mathrm{X}, \mathrm{Y}, \mathrm{Z}$ characteristics from the geometrically ideal plant, was low.

\section{REFERENCES}

Bernardo R (2010). Breeding for quantitative traits in plants. 2nd edn. Stemma, Woodbury, 390.

Cabral PDS, Soares TCB, Lima ABP, Soares YJB, et al. (2011). Análise de trilha do rendimento de grãos de feijoeiro (Phaseolus vulgaris L.) e seus componentes. Rev. Cienc. Agr 42: 132-138. http://dx.doi.org/10.1590/S1806$\underline{66902011000100017}$

Coelho ADF, Cardoso AA, Cruz CD, de Andrade Araújo GA, et al. (2002). Herdabilidade e correlações da produção do feijão e dos seus componentes primários, nas épocas de cultivo da primavera-verão e do verão-outono. Cienc. Rural 32: 211-216. http://dx.doi.org/10.1590/S0103-84782002000200005

Falconer DS and Mackay TFC (1996). Introduction to quantitative genetics, 4th edn. Longman Group Limited, Edinburgh, 464.

Grafius JE (1964). A geometry for plant breeding. Crop Sci. 3: 241-246. http://dx.doi.org/10.2135/ cropsci1964.0011183X000400030001x

Lana AMQ, Cardoso AA and Cruz CD (2003). Herdabilidades e correlações entre caracteres de linhagens de feijão obtidas em monocultivo e em consórcio com milho. Cienc. Rural 33: 1031-1037. http://dx.doi.org/10.1590/S0103$\underline{84782003000600006}$

Ramalho MAP, Andrade LAB and Teixeira NCS (1979). Correlações genéticas e fenotípicas entre caracteres do feijão (Phaseolus vulgaris L.). Cienc. Pratica 3: 63-70.

Ramalho MAP, Abreu ÂFB, Santos JBS and Nunes JAR (2012). Aplicações da genética quantitativa no melhoramento de plantas autógamas, 1st edn. Universidade Federal de Lavras, Lavras.

Ribeiro ND, Domingues L and Zemolin AEM (2014). Avaliação dos componentes da produtividade de grãos em feijão de grãos especiais. Cientifica 42: 178-186. http://dx.doi.org/10.15361/1984-5529.2014v42n2p178-186

Santos JB dos, Vencovsky R and, Ramalho MAP (1985). Controle genético da produção de grãos e de seus componentes primários em feijoeiro. Pesq. Agr. Bras. 20: 1203-1211.

Sarafi A (1978). A yield component selections experiment involving American and Iranian cultivars of the common bean. Crop Sci. 8: 5-15. http://dx.doi.org/10.2135/cropsci1978.0011183X001800010002x

Souza EA and Ramalho MAP (1995). Estimates of genetic and phenotypic variance of some traits of dry bean using a segregant population from the cross Jalo x Small White. Rev. Bras. Genet. 18: 87-91.

Zilio M, Coelho CMM, Souza CA, Santos JCP, et al. (2011). Contribuição dos componentes de rendimento na produtividade de genótipos crioulos de feijão (Phaseolus vulgaris L.). Rev. Cienc. Agr 42: 429-438. http://dx.doi.org/10.1590/ $\underline{\text { S1806-66902011000200024 }}$ 